\title{
Distribution of bacteria in the mineral waters of the Polish Lowlands
}

\author{
Maciej WALCZAK ${ }^{1}$, Edyta DEJA-SIKORA ${ }^{1, *}$, Agnieszka KALWASIŃSKA ${ }^{1}$, Marcin POLATOWSKI $^{1}$ \\ and Arkadiusz KRAWIEC ${ }^{2}$
}

1 Nicolaus Copernicus University, Faculty of Biology and Environmental Protection, Department of Environmental Microbiology and Biotechnology, Lwowska 1, 87-100 Toruń, Poland

2 Nicolaus Copernicus University, Faculty of Earth Sciences, Department of Geology and Hydrogeology, Lwowska 1, 87-100 Toruń, Poland

Walczak, M., Deja-Sikora, E., Kalwasińska, A., Polatowski, M., Krawiec, A., 2017. Distribution of bacteria in the mineral waters of the Polish Lowlands. Geological Quarterly, 61 (1): 177-185, doi: 10.7306/gq.1329

\begin{abstract}
The paper presents the results of research into the distribution of microorganisms in brines with the total dissolved solids of $40-80 \mathrm{~g} / \mathrm{dm}^{3}$, found in the Paleozoic platform of the Polish Lowlands. Water samples were collected from boreholes extracting water from the Jurassic and Triassic aquifers. The total number of microorganisms in the examined water samples ranged from 10 to $30 \times 10^{3}$ cells per $1 \mathrm{~cm}^{3}$, while their viability ranged from 14 to $58 \%$. The samples contained heterotrophic, chemoautotrophic, aerobic and anaerobic bacteria as well as bacteria participating in the transformation of iron and sulphur compounds. Molecular identification of culturable bacteria isolated from water samples revealed that they belong to six genera: Bacillus and Staphylococcus within phylum Firmicutes, Micrococcus and Kocuria within phylum Actinobacteria, and Marinobacter and Pseudoalteromonas within phylum Proteobacteria (class Gammaproteobacteria). The most abundant were Bacillus and Micrococcus isolates related to six different species: B. amyloliquefaciens, B. pumilus, B. methylotrophicus, B. licheniformis, M. luteus and M. yunnanensis.
\end{abstract}

Key words: bacteria, $16 \mathrm{~S}$ rDNA, brines, mineral waters

\section{INTRODUCTION}

Underground habitats are a substantial part of the biosphere. Life beneath the Earth's surface reaches farther down than it was believed some 30 years ago. A variety of microorganisms live at great depths, often under extreme conditions, i.e. high pressure, temperature, and/or salinity. According to Whitman et al. (1998) approximately $75-94 \%$ of prokaryotic organisms found on Earth live underground. Moreover, recent research indicates that the biomass of organisms found underground exceeds considerably the biomass of organisms on the Earth's surface (Adhikari and Kallmeyer, 2010). Microorganisms inhabiting subsurface niches (including deep groundwater) are often fully active and affect the pace and the direction of geological transformations like minerals formation and dissolution (Onstott et al., 1998; Griebler and Lueders, 2009; Łebkowska and Karwowska, 2010).

Brines, whose mineral content exceeds $35 \mathrm{~g} / \mathrm{dm}^{3}$, constitute a significant part of mineral waters commonly found in the Polish Lowlands in Mesozoic formations. North-west and central Poland is known to have the largest resources of mineral waters

*Corresponding author, e-mail: dejasikora@umk.pl

Received: January 15, 2016; accepted: May 11, 2016; first published online: November 29, 2016 containing mainly chloride, sodium and calcium ions. Since these mineral waters are widely used for recreation and balneotherapy in many spas across the Polish Lowlands, they are regularly monitored with regard to their chemistry while their microbiome is poorly investigated. The objective of the research was to determine whether and to which extent mineral waters of Mesozoic formations in this area are inhabited by microorganisms.

\section{GEOLOGY AND HYDROGEOLOGY}

The investigated region stretching in the north-west and central Poland is part of the Paleozoic platform. The area comprises large NW-SE-trending geological structures, including the Marginal Synclinorium, Mid-Polish Anticlinorium, Szczecin-Łódź-Miechów Synclinorium, and parts of the Sudetic and Silesian-Cracow monoclines. Zechstein salt layers had a great influence on the formation of mineral water deposits, particularly in the areas of the leaching of the halokinetic structures. The largest mineral water resources are located in the Lower Cretaceous, Jurassic and Triassic sediments (Fig. 1). Chloride and sodium mineral waters prevailing in this area are frequently exploited for therapeutic purposes in spas (e.g., Konstancin-Jeziorna, Grudziądz, Kamień Pomorski, Kołobrzeg, Połczyn, Ciechocinek and Świnoujście).

The geological structure and tectonic faults contribute greatly to the ascension of mineral chloride waters, that occasionally move upwards to appear on the surface or close to it. 


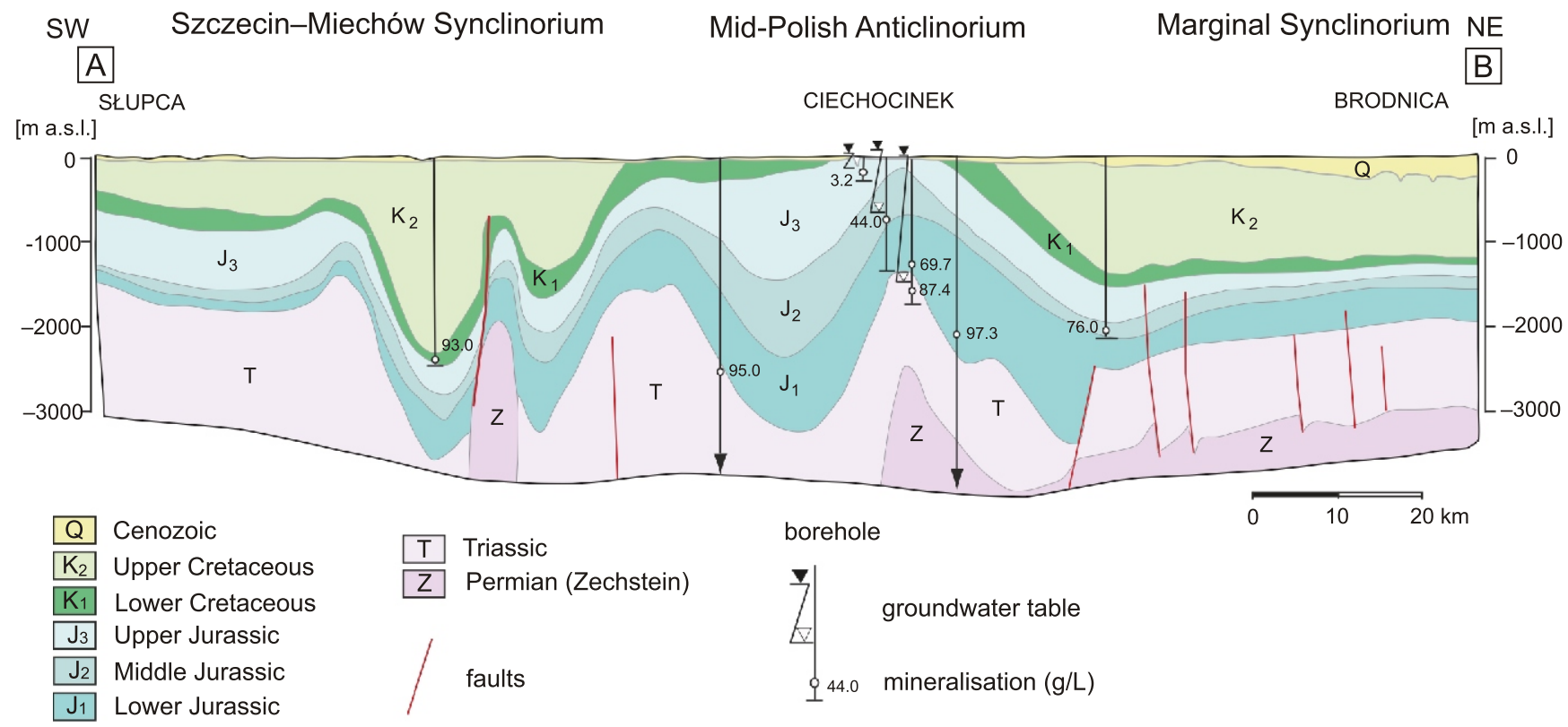

Fig. 1. Geological cross-section through the Polish Lowlands (Górecki, 2006, modified)

In the vicinity of Kamień Pomorski, Kołobrzeg, Łęczyca, Kowal and Ciechocinek (Dowgiałło, 1971; Krawiec et al., 2002) mineral water from numerous underground springs discharging at the surface became the basis for the salt industry as early as in the 9th century. The town of Kołobrzeg was a major trading centre for salt obtained in the saltworks located at the Parsęta River. Currently, Wyspa Solna (Salt Island) in the town's centre features mineral springs no. 18 and 35 , with the mineral content of approximately $51 \mathrm{~g} / \mathrm{dm}^{3}$.

Initially, it was suggested that high salinity of mineral waters found in the Polish Lowlands was associated with the dissolution of Zechstein salts (Kolago, 1964; Dowgiałło, 1965). Later, the contribution of fossil seawater was suspected (Dowgiałło, 1971). Finally, the presence of waters of mixed origin (fossil water and infiltration water) was indicated, however, with the predominant contribution of syndepositional waters or palaeoinfiltration seawater (Dowgiałło and Tongiorgi, 1972). Further studies of oxygen and hydrogen isotopes enabled classifying the mineral waters of north-west and central Poland as palaeoinfiltration waters from warmer pre-Pleistocene geological epochs (Zuber and Grabczak, 1991; Krawiec et al., 2000). In some cases, the contribution of fossil seawater cannot be excluded (Zuber et al., 2007).

Isotope analyses indicated that the stable isotope composition in this type of waters ranges between the values typical of seawater $\left(\delta^{18} \mathrm{O} \approx 0 \%\right.$ i $\delta^{2} \mathrm{H} \approx 0 \%$ o $)$ and of contemporary infiltration waters $\left(\delta^{18} \mathrm{O}\right.$ about $-10 \%$ and $\delta^{2} \mathrm{H}$ about $-70 \%$ o), which may be perceived as the result of mixing seawater with infiltration waters (Zuber et al., 2007). The high salinity (often exceeding the seawater salinity) and high values of several hydrochemical indicators (e.g., $\mathrm{rNa} / \mathrm{rCl}>1$ and $\mathrm{Cl} / \mathrm{Br}>300$ ) cannot be easily interpreted. In the brine samples collected near Ciechocinek the chlorides concentration was not correlated with their isotope composition (Zuber and Grabczak, 1991; Krawiec, 1999). This confirms the hypothesis that these brines can be regarded as meteoric water derived from infiltration which occurred in different climates, particularly in the warm pre-Quaternary climates. Their high salinity is related mainly to the leaching of Zechstein salt layers. An important argument supporting infiltration as the origin of these mineral waters is their tendency to run horizontally on $\mathrm{Cl}^{-}-\delta^{2} \mathrm{H}$ (and/or $\mathrm{Cl}^{-}-\delta^{18} \mathrm{O}$ ) diagrams, with values that exclude the contribution of seawater and/or seawater enriched by evaporation or ultrafiltration (Zuber et al., 2007).

As it was aforementioned, these brines may have originated from seawater or from the leaching of Zechstein salt layers, or even from the combination of these two factors; none of these excludes the presence of microorganisms. Classifying them as fossil seawater leads to the assumption that the microorganisms inhabiting these waters are of marine origin and the entire ecosystem is isolated from the rest of the world but still functioning. On the other hand, classifying them as infiltration waters percolating through Zechstein salt layers leads to the assumption that the microorganisms inhabiting these waters are derived from the salt deposits where they were trapped in the past geological epochs (Dombrowski, 1966). In this case the microorganisms would be a small part of the old community, which managed to survive, but did not find appropriate conditions for regular growth.

\section{MATERIALS AND METHODS}

Samples of mineral water (brine) were collected from five intakes marked with letters: Ciechocinek (A), Kołobrzeg (B-1, B-2, B-3) and Połczyn (C), located in the Marginal Synclinorium and the Mid-Polish Anticlinorium, from a depth of 100-1700 m (Fig. 2).

Sampling was aimed at $\mathrm{Cl}-\mathrm{Na}$ brines whose mineral content ranged from 40 to $80 \mathrm{~g} / \mathrm{dm}^{3}$ (Table 1). Some of the examined waters are used for recreational or therapeutic purposes (balneotherapy) in baths or swimming pools. These waters are well-isolated from the surface and located in the zone of very slow groundwater circulation. Their resources are poorly renewable.

Water samples for microbiological investigation were collected directly from the valve on the water pumps at the water's natural discharges. Prior to the sampling, stagnant water was drained from the water system and the valve was heat-sterilized in the flame. Water samples (the volume of $1.0 \mathrm{dm}^{3}$ each) were collected to sterile glass bottles. 


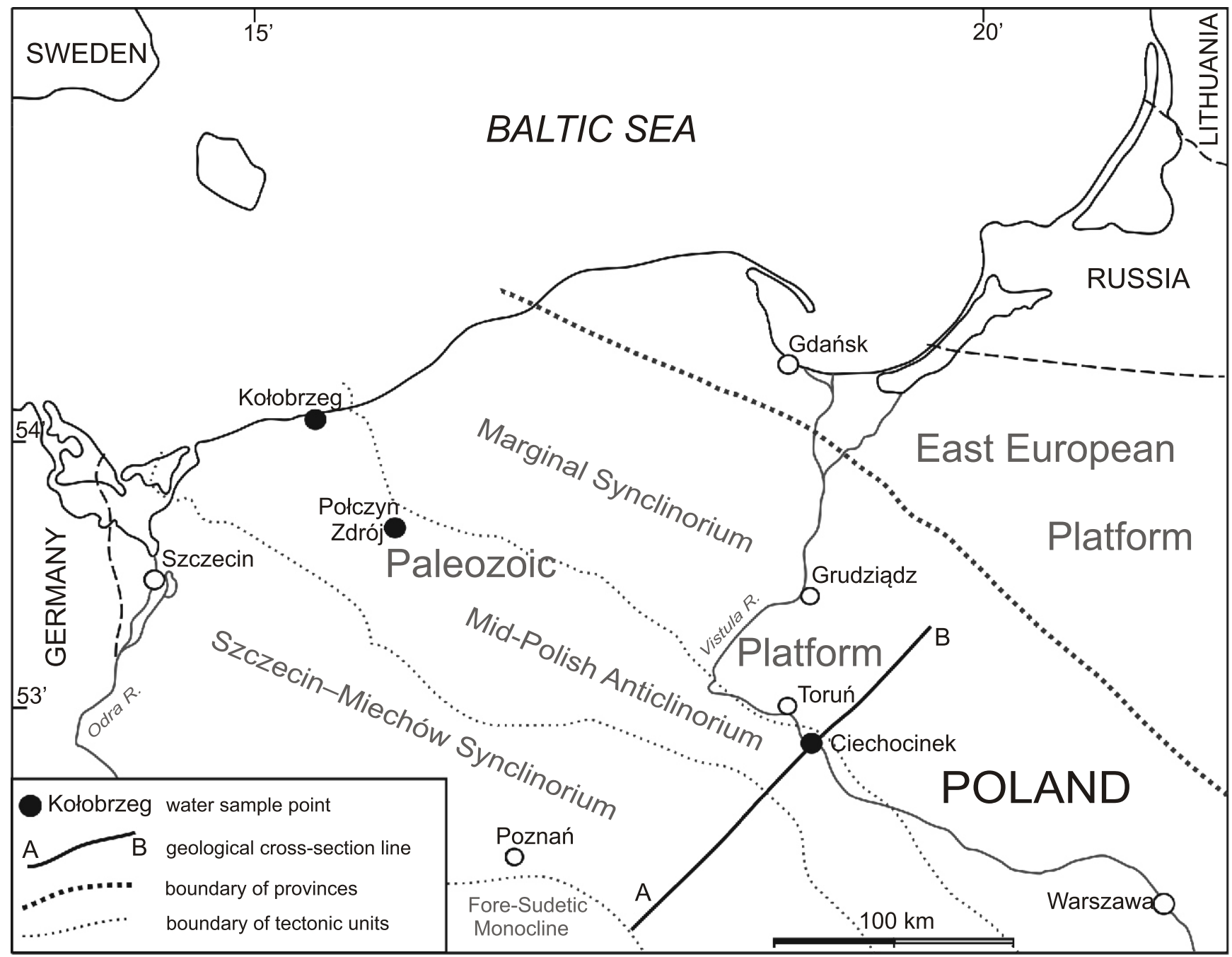

Fig. 2. Location of water sample collection sites (black dots)

Physical and chemical parameters of water samples are given according to Walczak and Krawiec (2014).

The total number of microorganisms (TNM) was determined by direct counting under the epifluorescence microscope. Testing involved filtering $100 \mathrm{~cm}^{3}$ of water through a polycarbonate membrane filter with a pore size of $0.22 \mu \mathrm{m}$. Microbial cells captured on the surface of the filter were stained with $100 \mathrm{mg} / \mathrm{dm}^{3}$ of acridine orange water solution. Prepared microscopic slides were immediately viewed under Olympus XC50 fluorescence microscope.

The viability of microorganisms in the water samples was determined in live/dead staining (Invitrogen). Testing involved filtering $100 \mathrm{~cm}^{3}$ of water through a polycarbonate membrane filter with a pore size of $0.22 \mu \mathrm{m}$. Microbial cells captured on the surface of the filter were stained with the mixture of propidium iodine and Syto Green stain. Prepared microscopic slides were immediately viewed under Olympus XC50 fluorescence microscope. Viable/alive cells (cells with intact membranes) stained green while dead cells (cells with damaged membranes) stained red or orange.

The number of aerobic and anaerobic heterotrophic bacteria (CFU) was determined by pour plate technique using Plate Count Agar (composition $\left[\mathrm{g} / \mathrm{dm}^{3}\right]$ : casein hydrolysate $15 \mathrm{~g}$, yeast extract $2.5 \mathrm{~g}$, glucose $1.0 \mathrm{~g}$, agar $15 \mathrm{~g}$ ). Each time, $1 \mathrm{ml}$ of water sample was transferred on a sterile Petri dish and poured with the medium cooled to $45^{\circ} \mathrm{C}$. All inoculations were per- formed in three parallel replicates. Anaerobic conditions were obtained by covering the PCA medium with the extra layer of water agar, which cut off oxygen. Grown colonies were counted every five days.

The number of aerobic and anaerobic chemoautotrophic bacteria was determined by the pour plate technique with the use of mineral growth medium based on water from the investigated spring (the composition of the medium: calcium lactate $1.0 \mathrm{~g}$, sodium succinate $-1.0 \mathrm{~g}$, iron gluconate $-1.0 \mathrm{~g}$, agar $15 \mathrm{~g}$, water from the investigated spring $1000 \mathrm{~cm}^{3}$ ).

The presence of spore-forming bacteria was tested by incubating water samples at $80^{\circ} \mathrm{C}$ for 20 minutes to inactivate vegetative cells and stimulate spores germination. $1 \mathrm{ml}$ of each heat-treated sample was transferred on a sterile Petri dish and poured with the PCA medium cooled to $45^{\circ} \mathrm{C}$. Samples were incubated in aerobic and anaerobic conditions. Colonies were counted every five days.

The presence and the number of $\mathrm{Fe}^{2+}$ oxidizing bacteria was determined by the most probable number (MPN) method using the medium of the following composition: $\left(\mathrm{NH}_{4}\right)_{2} \mathrm{SO}_{4}-$ $3.0 \mathrm{~g} ; \mathrm{CaCl}_{2}-0.1 \mathrm{~g} ; \mathrm{K}_{2} \mathrm{HPO}_{4}-0.5 \mathrm{~g} ; \mathrm{MgSO}_{4} \times 7 \mathrm{H}_{2} \mathrm{O}-0.5 \mathrm{~g}$; $\mathrm{Ca}\left(\mathrm{NO}_{3}\right)_{2}-0.01 \mathrm{~g} ; \mathrm{H}_{2} \mathrm{SO}_{4}(10 \mathrm{M})-1 \mathrm{ml} ; \mathrm{FeSO}_{4}-45.0 \mathrm{~g} ; \mathrm{pH}-$ 3.0-3.5. The incubation was conducted for 20 days at the temperature similar to that of the spring. Rusty colour of the medium indicated the oxidation of $\mathrm{Fe}^{2+}$ to $\mathrm{Fe}^{3+}$. 
Physical and chemical parameters of the water samples

\begin{tabular}{|c|c|c|c|c|c|}
\hline Sample & $\begin{array}{c}\text { Ciechocinek } \\
\text { (A) }\end{array}$ & $\begin{array}{c}\text { Kołobrzeg } \\
(B-1)\end{array}$ & $\begin{array}{c}\text { Kołobrzeg } \\
(B-2)\end{array}$ & $\begin{array}{c}\text { Kołobrzeg } \\
\text { (B-3) }\end{array}$ & $\begin{array}{l}\text { Połczyn } \\
\text { (C) }\end{array}$ \\
\hline Components & \multicolumn{5}{|c|}{$\left[\mathrm{mg} / \mathrm{dm}^{3}\right]$} \\
\hline $\begin{array}{l}\text { Total dissolved solids } \\
\text { (TDS) }\end{array}$ & 44000.0 & 60200.0 & 60400.0 & 55100.0 & 75000.0 \\
\hline $\mathrm{Ca}^{2+}$ & 1320.0 & 2160.0 & 2020.0 & 1940.0 & 3100.0 \\
\hline $\mathrm{Mg}^{2+}$ & 490.0 & 700.0 & 690.0 & 705.0 & 870.0 \\
\hline $\mathrm{Na}^{+}$ & 14700.0 & 19900.0 & 20100.0 & 18000.0 & 24000.0 \\
\hline $\mathrm{K}^{+}$ & 163.2 & 150.0 & 140.0 & 115.0 & 55.0 \\
\hline $\mathrm{Fe}^{2+}$ & 1.3 & 16.2 & 8.0 & 10.8 & 3.4 \\
\hline $\mathrm{HCO}_{3}^{-}$ & 356.0 & 230.0 & 250.0 & 232.0 & 60.0 \\
\hline $\mathrm{SO}_{4}^{-}$ & 97.0 & 330.0 & 360.0 & 295.0 & 3100.0 \\
\hline $\mathrm{Cl}^{-}$ & 26230.0 & 36300.0 & 36500.0 & 33300.0 & 42700.0 \\
\hline $\mathrm{F}^{-}$ & 0.6 & - & 0.0 & - & 0.15 \\
\hline $\mathrm{J}^{-}$ & 2.1 & 4.7 & 3.5 & 5.4 & 2.2 \\
\hline $\mathrm{Br}^{-}$ & 7.4 & 77.0 & 100.0 & 125.0 & 195.0 \\
\hline $\begin{array}{l}\mathrm{S}(\mathrm{II}) \text { compounds } \\
\left(\mathrm{H}_{2} \mathrm{~S}+\mathrm{HS}^{-}\right)\end{array}$ & 0.90 & - & - & - & - \\
\hline $\mathrm{pH}$ & 6.9 & 7.2 & 6.9 & 6.9 & 7.8 \\
\hline Eh [mV] & +10.8 & -5.2 & +16.5 & +14.4 & -35.9 \\
\hline $\begin{array}{l}\text { Depth of extraction } \\
\text { [m] }\end{array}$ & 750 & 300 & 200 & 100 & 1200 \\
\hline Water type & $\mathrm{Cl}-\mathrm{Na}, \mathrm{J}$ & $\mathrm{Cl}-\mathrm{Na}, \mathrm{J}, \mathrm{Fe}$ & $\mathrm{Cl}-\mathrm{Na}, \mathrm{J}$ & $\mathrm{Cl}-\mathrm{Na}, \mathrm{J}, \mathrm{Fe}$ & $\mathrm{Cl}-\mathrm{Na}, \mathrm{J}$ \\
\hline
\end{tabular}

The presence and the number of sulphate-reducing bacteria (SRB) was determined by the most probable number (MPN) method using the medium of the following composition: [base: $\mathrm{K}_{2} \mathrm{HPO}_{4}-0.5 \mathrm{~g} ; \mathrm{NH}_{4} \mathrm{Cl}-1.0 \mathrm{~g} ; \mathrm{Na}_{2} \mathrm{SO}_{4}-1.0 \mathrm{~g} ; \mathrm{CaCl}_{2} \times 2 \mathrm{H}_{2} \mathrm{O}-$ $0.1 \mathrm{~g} ; \mathrm{MgSO}_{4} \times 7 \mathrm{H}_{2} \mathrm{O}-2.0 \mathrm{~g}$; sodium lactate $(70 \%)-3.5 \mathrm{~g}$; sodium pyruvate $-0.5 \mathrm{~g}$; yeast extract $-1.0 \mathrm{~g} ; \mathrm{H}_{2} \mathrm{O}-980 \mathrm{ml} ; \mathrm{pH}-$ 7.4; solution 2: $(2-10 \mathrm{ml}) \mathrm{FeSO}_{4} \times 7 \mathrm{H}_{2} \mathrm{O}-0.5 \mathrm{~g}$; solution $3-$ $(10 \mathrm{ml})$ : ascorbic acid $-0.1 \mathrm{~g}$; sodium thioglicolate $-0.1 \mathrm{~g}$ ]. Solutions 2 and 3 were sterilized by filtration through a syringe filter and then added to the base after it had been sterilized in an autoclave. After inoculation, $2 \mathrm{ml}$ of sterile paraffin oil was introduced on the surface of each sample in order to cut off oxygen. The incubation was conducted for 20 days at the temperature similar to that of the spring. Black colour of the medium indicated the reduction of sulphates and sulphites to hydrogen sulphide (which, combined with iron ions, produces black iron sulphide).

Total genomic DNA was obtained from all environmental isolates by the standard molecular biology method. Bacterial cells forming a single colony were picked from the agar plate with an inoculating loop, resuspended in buffer consisting of $50 \mathrm{mM}$ Tris-Cl pH 8.0, $20 \mathrm{mM}$ EDTA pH 8.0 and lysozyme $(1 \mathrm{mg} / \mathrm{ml})$. Samples were incubated for 30 minutes at $37^{\circ} \mathrm{C}$. Then, SDS was added to the final concentration of $1 \%$, and samples were incubated for 1 hour at $60^{\circ} \mathrm{C}$. Genomic DNA was extracted with 1 volume of phenol/chloroform/isoamyl alcohol mixture, then precipitated from the aqueous phase with 0.7 volume of 2-propanol, washed with $70 \%$ ethanol, air dried and redissolved in nuclease-free water.

Molecular identification of environmental isolates was based on a sequence of $16 \mathrm{~S}$ rDNA amplicons. Fragments of 16S rDNA sequences were generated by the $P C R$, using a pair of the universal bacterial primers (27F: AGA GTT TGA TCA TGG CTC AG and 1492R: GGT ACC TTG TTA CGA CTT). Reaction mixtures contained: 5 ng of genomic DNA as a tem- plate, $0.2 \mathrm{mM}$ dNTPs, $0.25 \mu \mathrm{M}$ primers, $1 \mathrm{U}$ HotStar Taq Polymerase (Qiagen) and $1 \times$ buffer with $1.5 \mathrm{mM} \mathrm{MgCl}_{2}$. The cycling conditions were as follows: initial denaturation at $95^{\circ} \mathrm{C}$ for 10 minutes, 35 cycles of denaturation at $95^{\circ} \mathrm{C}$ for 30 seconds, annealing at $52^{\circ} \mathrm{C}$ for 30 seconds, and elongation at $72^{\circ} \mathrm{C}$ for 90 seconds, and final extension at $72^{\circ} \mathrm{C}$ for 5 minutes. Amplicons (about 1400 bp long) were purified and their concentrations were measured with NanoDrop ND-1000 spectrophotometer. Sequencing of amplicons was performed with BigDye Terminator v3.1 Cycle Sequencing Kit (Applied Biosystems), according to manufacturer's instructions. For each $16 \mathrm{~S}$ rDNA amplicon, both DNA strands were sequenced, using aforementioned PCR primers (27F and $1490 \mathrm{R})$. Sequencing reaction products were analysed with ABI3730 Genetic Analyzer (Oligo IBB PAS, Warsaw, Poland). 16S rDNA reads were assembled and edited. Good quality $16 S$ rDNA fasta sequences were used to search the Genbank nr/nt database with BLASTN for the closest homologs. Species identification was based on BLASTN results and confirmed with EzTaxon using a $3 \%$ dissimilarity level as a cutoff. All 16S rDNA sequences were deposited to GenBank under accession numbers KX108866-KX108885.

\section{RESULTS}

The total number of microorganisms in the examined water samples is presented in Figure 3. The values ranged from several thousand to 30 thousand cells $/ \mathrm{cm}^{3}$ of water. The highest total numbers of microorganisms were determined in samples from intakes A $\left(29.8 \times 10^{3}\right.$ cells $\left./ \mathrm{cm}^{3}\right)$ and B-3 $(28.9 \times$ $10^{3} \mathrm{cells} / \mathrm{cm}^{3}$ ), while the lowest number of microorganisms was observed in those from intake B-1 $\left(9.9 \times 10^{3} \mathrm{cells} / \mathrm{cm}^{3}\right)$.

The viability of microorganisms in the samples was relatively high. Almost 50 and $60 \%$ of microbial cells were alive in samples from intakes A and B-3, respectively. The lowest viabil- 


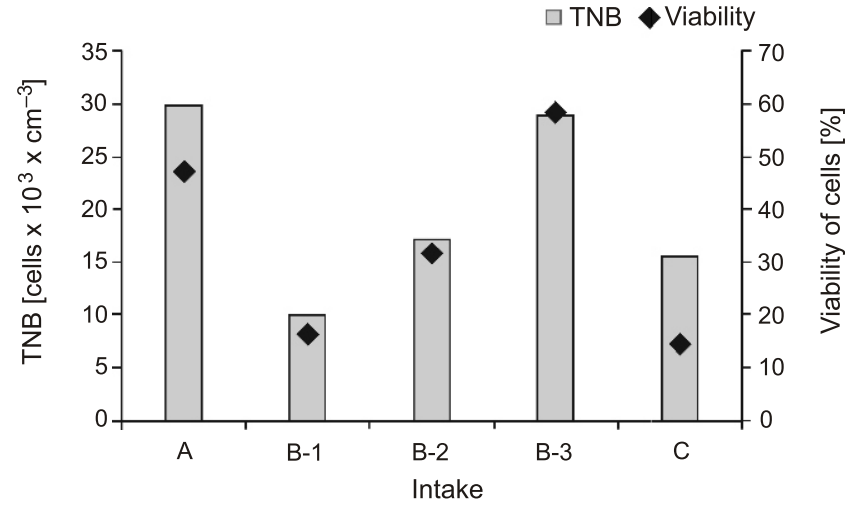

Fig. 3. Total number of microorganisms and the viability of microbial cells in the water samples

TNB - total number of bacteria

ity was noticed in those from intakes $C$ and $B-1$, in which only 14 and $16 \%$ of microbial cells were alive, respectively.

In all investigated waters the number of heterotrophic microorganisms was relatively low. The highest number of aerobic heterotrophic microorganisms $\left(22 \mathrm{CFU} / \mathrm{cm}^{3}\right)$ was determined in water samples from intake B-3. In the others the total number of aerobic bacteria was slightly lower and ranged from 11 to $17 \mathrm{CFU} / \mathrm{cm}^{3}$.

The highest number of anaerobic microorganisms capable of growing (forming colonies) on the applied media was noticed in samples from intakes B-2 and C $\left(5.5 \mathrm{CFU} / \mathrm{cm}^{3}\right)$. No such microorganisms were identified in water samples from intake B-3.

Chemoautotrophic microorganisms were identified only in waters from intakes A, B-3 and C (Fig. 4). In sample A the number of aerobic chemoautotrophic microorganisms was $1 \mathrm{CFU} / \mathrm{cm}^{3}$, while the number of anaerobic chemoautotrophic microorganisms was $3 \mathrm{CFU} / \mathrm{cm}^{3}$. In samples B-3 and C, only aerobic chemoautotrophic microorganisms were identified in the quantity of 2 and $1.5 \mathrm{CFU} / \mathrm{cm}^{3}$, respectively. No spore-forming bacteria were detected in all tested water samples.

$\mathrm{Fe}^{2+}$ oxidizing bacteria were identified in all water samples, with the highest numbers found in a water sample from intake A, where MPN was $240 / 10 \mathrm{~cm}^{3}$. Their quantity in the remaining samples was at least ten times lower (Fig. 5).

Bacteria reducing sulphates and other oxidised forms of sulphur were identified only in water samples from intakes $A$ and $B-1$. However, their quantities were very low with the MPN value reaching only 2.5 per $10 \mathrm{~cm}^{3}$.

Among culturable isolates, retrieved from each investigated water sample, colonies differing in morphological characteristics were chosen for molecular identification. Taxonomic affiliation of bacteria was based on 16S rDNA sequence similarity. The species and strains being the closest genetic relatives of environmental isolates are given in the Table 2.

Bacteria related to four different Bacillus species: $B$. amyloliquefaciens, B. pumilus, B. methylotrophicus, B. licheniformis, were detected in waters $A, B-1, B-2$ and $B-3$ coming from Ciechocinek and Kołobrzeg, while no Bacillus isolates were found in water $C$ from Połczyn. Actinobacteria reported in four water samples, excluding sample A, were relatives of species Micrococcus luteus, M. yunnanensis and Kocuria palustris. Two Staphylococcus species related to $S$. pasteuri and $S$. haemolyticus were found in samples $A$ and $C$, respectively. Gammaproteobacteria were isolated only from waters B-2 and B-3 (Kołobrzeg) and they were closely related to species Marinobacter lipolyticus and Pseudoalteromonas issachenkonii, respectively.

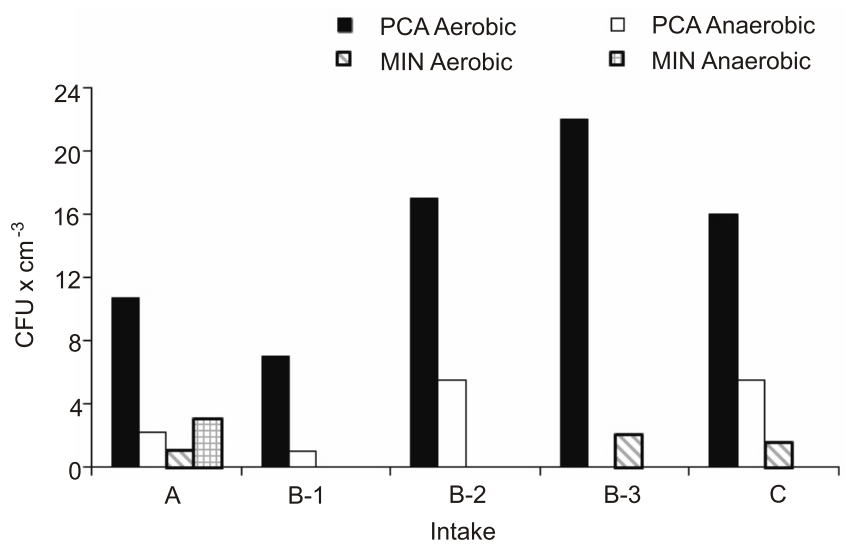

Fig. 4. Number of heterotrophic and chemoautotrophic bacteria in the water samples

PCA - PCA medium, MIN - mineral medium

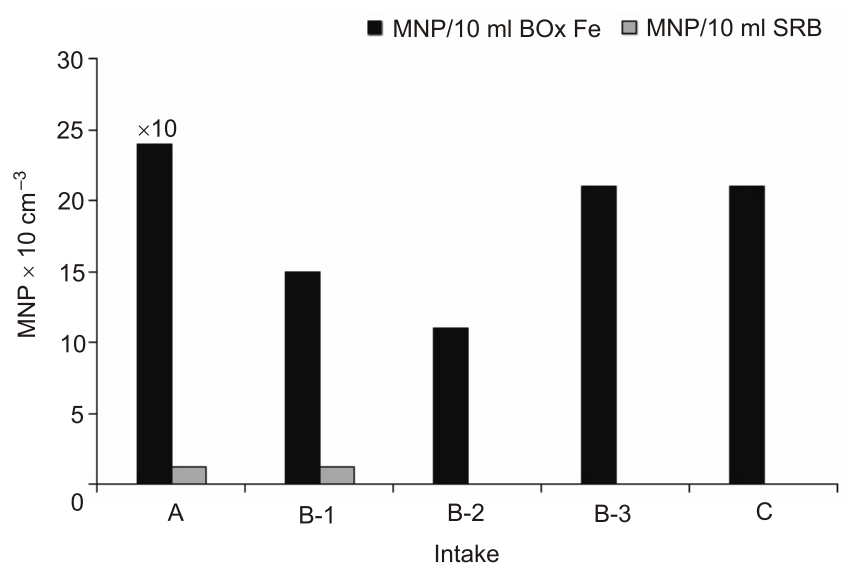

Fig. 5. Most probable number of microorganisms capable of $\mathrm{Fe}$ oxidation and $\mathrm{S}$ reduction

$\mathrm{BO} \times \mathrm{Fe}$ - bacteria oxidizing $\mathrm{Fe}^{2+}$; SRB - sulphate-reducing bacteria

\section{DISCUSSION}

Microbial life is thriving in deep underground water reservoirs, however, our knowledge of microorganisms inhabiting such isolated and extreme environments is poor and needs to be expanded. The pioneering research, which aimed at investigating microorganisms living in the brines of the Wieliczka salt mine (Poland), demonstrated that underground saline waters are a regular habitat for bacteria (Namyslowski, 1913). Further research involved examining samples of Zechstein salt collected in Germany (Dombrowski, 1966). The results indicated that a number of bacteria were trapped in salt crystals. Bacterial cells, inactive due to extreme dehydration, restored their activity after being introduced into growth media. Following his research, Dombrowski (1963) hypothesized that dehydration combined with high salinity may keep bacterial cells alive for millions of years.

The results presented in this paper indicate that a large number of microorganisms are present in the brines deposited in the Mesozoic formations of the Polish Lowlands. The highest total number of microorganisms were found in intakes A and B-3 (close to $30 \times 10^{3}$ cells $/ \mathrm{cm}^{3}$ ). The observation is similar to that 
Molecular identification of bacterial isolates based on 16S rDNA similarity

\begin{tabular}{|c|c|c|c|c|c|c|}
\hline \multirow{2}{*}{ Sampling site } & \multirow{2}{*}{ Intake } & \multirow{2}{*}{ Isolate } & \multicolumn{4}{|c|}{ The closest 16S rDNA relative } \\
\hline & & & Species & Strain & Reference source of isolation & Similarity [\%] \\
\hline \multirow{4}{*}{ Ciechocinek } & \multirow{4}{*}{ A } & 1 & Bacillus amyloliquefaciens & D8 & Not known & 99 \\
\hline & & 2 & Bacillus amyloliquefaciens & Zzx45 & Not known & 100 \\
\hline & & 3 & Staphylococcus pasteuri & $\mathrm{HN}-35$ & Spacecraft surface & 100 \\
\hline & & 4 & Staphylococcus pasteuri & $\mathrm{HN}-35$ & Spacecraft surface & 99 \\
\hline \multirow{12}{*}{ Kołobrzeg } & \multirow{4}{*}{ B-1 } & 1 & Bacillus pumilus & HNS70 & Marine sediment & 100 \\
\hline & & 2 & Micrococcus sp. & JNU-H022 & Marine sediment & 99 \\
\hline & & 3 & Bacillus methylotrophicus & HB26 & Tobacco rhizospheric soil & 99 \\
\hline & & 4 & Micrococcus yunnanensis & KNUC422 & Not known & 99 \\
\hline & \multirow{4}{*}{ B-2 } & 1 & Micrococcus luteus & $\mathrm{HN}-40$ & Spacecraft surface & 99 \\
\hline & & 2 & Micrococcus yunnanensis & KNUC422 & Not known & 99 \\
\hline & & 3 & Marinobacter lipolyticus & SM-19 & Not known & 99 \\
\hline & & 4 & Bacillus amyloliquefaciens & BS22 & Soil & 100 \\
\hline & \multirow{4}{*}{$B-3$} & 1 & $\begin{array}{c}\text { Pseudoalteromonas } \\
\text { issachenkonii }\end{array}$ & $\mathrm{XH} 148$ & Bottom seawater & 99 \\
\hline & & 2 & Bacillus amyloliquefaciens & Jc-07 & Farmland soil & 99 \\
\hline & & 3 & Kocuria palustris & $\mathrm{XH} 182$ & Deep-sea sediment & 99 \\
\hline & & 4 & Bacillus licheniformis & TS_10 & Hot spring & 99 \\
\hline \multirow{4}{*}{ Połczyn } & \multirow{4}{*}{ C } & 1 & Kocuria sp. & $13-2-9$ & South China Sea & 99 \\
\hline & & 2 & Kocuria sp. & $13-2-8$ & South China Sea & 99 \\
\hline & & 3 & Staphylococcus haemolyticus & CIFRI P-TSB-72 & Marine water from Puri & 99 \\
\hline & & 4 & Micrococcus sp. & $\mathrm{A} 1$ & Wetlands & 99 \\
\hline
\end{tabular}

presented in the papers of Sass and Cypionka (2004), who examined brines extracted from a depth of 580-1060 m near Berlin, Germany. Other researchers also determined the total number of microorganisms as being close to $10^{4} \mathrm{cells} / \mathrm{cm}^{3}$ (Lovley and Goodwin, 1988; Pedersen and Ekendahl, 1990), which may be the limit value in many types of groundwater with a very low concentration of organic carbon (Lovley and Goodwin, 1988; Fry et al., 1997). Colwell et al. (1997) reported that organic matter recharging from the surface is very slow in most of deep underground environments. Therefore, the flux of soluble nutrients is extremely limited, which strongly constrains the abundance of indigenous microorganisms.

The number of culturable heterotrophic microorganisms in the studied water samples was very low compared to the total number of viable cells. This may result from growth limitations due to insufficient amount of specific nutrients or growth factors (Sand, 2003). The sample from intake B-3 had the highest number of microorganisms capable of growing on media containing organic carbon compounds ( $22 \mathrm{CFU} / \mathrm{cm}^{3}$ in total). The majority of retrieved microorganisms grew under aerobic conditions, which may seem unexpected considering that underground waters are oxygen-deficient. However, researches show that microbial metabolic strategies found in deep subsurface ecological niches are similar to those found in surface environments. Many isolates obtained from deep aquifers and sediments use aerobic metabolism for organic matter oxidation (Balkwill et al., 1989). Oxygen-based metabolism is favoured because it yields most energy, but under $\mathrm{O}_{2}$-depleted conditions many microbes couple the oxidation of organic compounds to the reduction of alternative terminal electron acceptors (TEAs), i.e. nitrates, $\mathrm{Mn}(\mathrm{IV})$ or $\mathrm{Fe}$ (III) (Lovely and Chapelle, 1995). Aerobic bacteria were shown to be indigenous to underground aquatic environments, however, they might also enter the deep aquatic systems with recharge water (Hicks et al., 1989).
Autotrophic microorganisms, growing only in the presence of mineral compounds, were found exclusively in the samples from intakes A, B-3 and C. Their quantity was very low and only single colony-forming units were identified in $1 \mathrm{~cm}^{3}$ of water.

In the examined water samples the number of microbial cells capable of growing on microbiological media was very low. The physiological state of bacterial cells was probably strongly affected by pressure changes. The number of colony-forming units compared to the observed total number of cells suggested reduced viability of bacteria. Moreover, the majority of environmental microorganisms are non-culturable, which particularly concerns water microbes living in Earth's deep layers and in the oceans, as it was mentioned by Krumholz (2000). Since only a small percentage of cells may be retrieved on a given medium, microbial communities estimated from aerobic and anaerobic culturing techniques probably represent the minimum viable biomass for the assessed samples. The "actual" biomass of viable subsurface microbiome likely resides between the estimates provided by the AODC (acridine orange direct counts) and MPN or CFU determinations (Onstott et al., 1998).

Bacteria, related to the known spore-forming Bacillus species, were present in four water samples (A, B-1, B-2 and B-3), however, spores were not detected via plate counts. This result might be related to the occurrence of unfavourable environmental conditions inhibiting spores production. It was reported that efficiency of sporulation process strongly depends on an appropriate carbon to nitrogen ratio as well as calcium and oxygen delivery. Sporulation was shown to be dramatically reduced under anaerobic conditions (Monteiro et al., 2014). In oligotrophic brines, sporulation is likely to be inhibited or reduced due to insufficient nutrients content and oxygen depletion. In addition, the few spores, produced under adverse environmental conditions, can be in a superdormant state, in which they have higher nutritional and temperature requirements for activation. Ghosh 
and Setlow (2009) showed that the germination of heat-treated superdormant spores could not be induced with basic nutrients because more complex mixtures of nutrients were required. The similar situation was likely to occur during our testing if the applied medium had non-optimal composition to trigger spores germination.

Autotrophic iron-oxidizing bacteria were also found in the examined water samples, which seems natural considering the fact that the samples contained significant amounts of $\mathrm{Fe}^{2+}$ ions (Table 1). On the other hand, iron bacteria are strict aerobes (Brock, 1997) and their presence in oxygen-depleted groundwater may seem surprising. Moreover, chemical analysis of the sampled waters indicated that biological oxidation of $\mathrm{Fe}^{2+}$ ions under the conditions found underground must be entirely or almost entirely inhibited, otherwise $\mathrm{Fe}^{2+}$ would be quickly oxidised to $\mathrm{Fe}^{3+}$. Therefore, it cannot be excluded that these bacteria do not originate from investigated groundwater, but have colonized the water pipes which pump water to the surface, and this is the reason why they were identified in the samples.

Anaerobic bacteria that reduce sulphates and sulphites were identified only in the samples from intakes A and B-1 (Fig. 5), while $\mathrm{SO}^{4-}$ ions, substrates used by $\mathrm{SRB}$, were found in all analysed waters. Metabolic product of SRB is either sulphur or hydrogen sulphide $\left(\mathrm{H}_{2} \mathrm{~S}\right)$; the presence of the latter in the samples from intake A may be related to the presence of these bacteria. Moreover, the $\mathrm{H}_{2} \mathrm{~S}$ can react with $\mathrm{Fe}^{2+}$ ions, thereby forming pyrite $\left(\mathrm{FeS}_{2}\right)$. Such transformations lead to a decrease in the amount of $\mathrm{Fe}^{2+}$ and $\mathrm{SO}^{4-}$ ions, which is reflected in the chemical composition of water from intake $A$, where the concentration of $\mathrm{Fe}^{2+}$ ions is the lowest (Table 1). In the water from intake B-1, $\mathrm{H}_{2} \mathrm{~S}$ has not been identified and there is no information about the presence of elemental sulphur. Nevertheless, this negative result may be caused by the deficiencies of the research methods. According to Adhikari and Kallmeyer (2010) SRB can only be detected by the culture method when a synthesis of the enzymes encoded by genes associated with the sulphate reduction takes place. Sulphate-reducing bacteria were identified in all samples from brines near Berlin (Sass and Cypionka, 2004). However, in their research the authors applied the pre-enrichment method, which significantly increased the number of microbial cells in the examined water samples. For this reason their results cannot serve as the reference mark and cannot be compared with the results presented in this paper

Molecular identification of culturable bacteria, which were retrieved from investigated samples, shed some light on the composition of microbiome inhabiting brines of the Polish Lowlands. Members of phyla Firmicutes and Actinobacteria predominated in analysed waters, contributing 50 and $40 \%$ of all isolates, respectively. The occurrence of particular taxonomic groups slightly differed between the samples. Two species identified in $4.4 \%$ brine (Ciechocinek) belong to Firmicutes. In more saline waters of Kołobrzeg $(5.5$ to $6 \% \mathrm{NaCl})$ the diversity of isolates was the highest and 10 identified species belong to three different phyla: Firmicutes, Actinobacteria and Proteobacteria (class Gammaproteobacteria). Actinobacteria and Firmicutes found in $7.5 \%$ brine (Połczyn) were represented only by 4 species. Our research revealed that investigated groundwater samples were commonly inhabited by culturable members of Firmicutes (genera Bacillus and Staphylococcus) and Actinobacteria (genera Micrococcus and Kocuria), irrespectively of sampling sites. The occurrence of Gammaproteobacteria was surprisingly rare. In other researches this bacterial group was indicated to be dominant in subsurface aquatic communities (Liu et al., 2014; Missimer et al., 2014). In our studies, Gammaproteobacteria were encoun- tered only in two shallowest brines, which might be related to the unknown specific parameters of these waters (i.e. temperature, pressure, or organic matter content). Nevertheless, all identified phyla seem to be indigenous to deep subsurface brines, as reported also by Beyer et al. (2015), who found that Proteobacteria (Gammaproteobacteria), Firmicutes and Actinobacteria were the dominant taxa in pristine, saline groundwater associated with Muschelkalk, Buntsandstein and Zechstein strata.

Among 20 isolates, obtained in this study, 11 different species were observed. The most abundant were bacteria related to four Bacillus species: $B$. amyloliquefaciens, $B$. pumilus, $B$. methylotrophicus and $B$. licheniformis ( 7 isolates). Bacilli are known for their highly diverse nature and ability to survive under extreme environmental conditions, including moderate and high salinity. Bacillus species, identified in this study, were reported to be widespread in saline waters. B. pumilus and $B$. licheniformis were isolated from seawater of different areas of the Pacific Ocean (Ivanova et al., 1999), as well as from deep ocean sediments (Ettoumi et al., 2009) and deep sea, hypersaline anoxic brine lakes (Sass et al., 2008). Many Bacillus species, including B. licheniformis and B. methylotrophicus, were identified among halophilic and halotolerant isolates retrieved from the brines of Karak Salt Mines in Pakistan. In addition, several Staphylococcus and Kocuria species were also found in aforementioned brines, but no Micrococcus representatives were observed (Roohi et al., 2014). Halotolerant Actinobacteria, K. palustris and Micrococcus yunnanesis, found during the present study, were reported to be isolated from a marine saltern of Goa (Ballav et al., 2015) and marine sponges Xestospongia muta of the Conch Reef, Florida (Palomo et al., 2013). Gammaproteobacteria were rare among the isolates obtained from studied brines and they were represented by relatives of two species, Marinobacter lipolyticus and Pseudoalteromonas issachenkonii. However, $M$. lipolyticus and $P$. issachenkonii are found to be halophilic/halotolerant microorganisms, which are known to be widely distributed in saline environments, i.e. soil, marine waters and sea ice (Martin et al., 2003; Liu et al., 2013). Observations done during the present investigation remain in consistence with those of other researchers. Reported species are described to be tolerant of high salinity and they exhibit a broad environmental distribution, therefore their common occurrence in brines of the Polish Lowlands can be expected.

The results presented in this paper indicate that waters in the deep aquifers of the Polish Lowlands are inhabited by microorganisms. The microbiological research on brines of the Polish Lowlands should be continued to extend the knowledge about the microorganisms living in such environment. Recognizing the microbial communities and their metabolic activities will result in better understanding of the water chemistry and chemical transformations which take place in this environment.

\section{CONCLUSIONS}

The research involved examining brines of the Polish Lowlands. Microbial life was detected in all water samples although the quantity of bacteria was varied. The highest total number of microorganisms was identified in the water samples from intakes A and B-3 (close to 30 thousand cells in $1 \mathrm{~cm}^{3}$ ). The number of heterotrophic microorganisms in the water samples was very low, which is probably due to the insufficient amount of nutrients in the water. Most of the isolated heterotrophic bacteria were capable of growing aerobically on media containing or- 
ganic carbon compounds. We detected only single autotrophic microorganisms, that grew in the presence of mineral compounds (samples A, B-3 and C). Autotrophic iron-oxidizing bacteria were commonly present in all investigated waters, while anaerobic bacteria reducing sulphates and sulphites were reported only in two samples (A and B-1).

Generally, the number of microbes retrieved on applied media was low compared with total cell counts. It is probably related to the observation that a large amount of microorganisms are non-culturable and therefore cannot be detected by regular microbial testing.
The investigation, in spite of the small number of taxonomically identified culturable bacteria, exhibited that bacilli and micrococci are common inhabitants of saline underground waters of the Polish Lowlands. However, more extensive studies are necessary to explain microbial diversity in brines.

Acknowledgements. We are grateful to the reviewers (E. Karwowska and an anonymous reviewer) and to the editor for their valuable suggestions and comments that helped to improve the paper.

\section{REFERENCES}

Adhikari, R.R., Kallmeyer, J., 2010. Detection and quantification of microbial activity in the subsurface. Chemie der Erde, 70 (Supplement 3): 135-143

Ballav, S., Kerkar, S., Thomas, S., Augustine, N., 2015. Halophilic and halotolerant actinomycetes from a marine saltern of Goa, India producing anti-bacterial metabolites. Journal of Bioscience and Bioengineering, 119: 323-330.

Balkwill, D.L., Fredrickson, J.K., Thomas, J.M, 1989. Vertical and horizontal variations in the physiological diversity of the aerobic chemoheterotrophic bacterial microflora in deep southeas coastal plain sediments. Applied and Environmental Microbiology, 55: 1058-1065.

Beyer, A., Rzanny, M., Weist, A., Möller, S., Burow, K., Gutmann, F., Neumann, S., Lindner, J., Müsse, S., Brangsch, H., Stoiber-Lipp, J., Lonschinski, M., Merten, D., Büchel, G., Kothe, E., 2015. Aquifer community structure in dependence of lithostratigraphy in groundwater reservoirs. Environmental Science and Pollution Research, 22: 19342-19351.

Brock, T.D., 1997. Prokaryotic diversity: Bacteria. In: Biology of Microorganisms (8th edn.) (eds. M.T. Madigan, J.M. Martinko and J. Parker): 661-664. Prentice-Hall International, Inc., New Jersey.

Colwell, F.S., Onstott, T.C., Dilwiche, M.E., Chandler, D., Fredrickson, J.K., Yao, Q-J, McKinley, J.P., Boone, D.R., Griffiths, R., Phelps, T.J., Ringelberg, D., White, D.C., LaFreniere, L., Balkwill, D.L., Lehman, R.M., Konisky, J., Long, P.E., 1997. Microorganisms from deep, high temperature, sandstones: constraints on microbial colonization. FEMS Microbiology Reviews, 20: 425-435.

Dombrowski, H., 1963. Bacteria from Paleozoic salt deposits. Annals of the New York Academy of Sciences, 108: 453-460.

Dombrowski, H., 1966. Geological problems in the question of living bacteria in Paleozoic salt deposits. In: Second Symposium on Salt (ed. J.L. Rau), 1: 215-219. Northern Ohio Geological Society, Cleveland, Ohio.

Dowgiałło, J., 1965. Solanki Pomorza Zachodniego (in Polish). Szczecińskie Towarzystwo Naukowe, Szczecin, IV Part 2: $1-122$.

Dowgiałło, J., 1971. Study on the origin of mineralized waters in Mesozoic formations of North Poland (in Polish with English summary). Biuletyn Geologiczny UW, 13: 133-224.

Dowgiałło, J., Tongiorgi, E., 1972. The isotopic composition of oxygen and hydrogen in some brines from the Mesozoic in northwest Poland. Geothermics, 1: 67-69.

Ettoumi, B., Raddadi, N., Borin, S., Daffonchio, D., Boudabous, A., Cherif, A., 2009. Diversity and phylogeny of culturable spore-forming Bacilli isolated from marine sediments. Journal of Basic Microbiology, 49: S13-S23.

Fry, N.K., Fredrickson, J.K., Fishbain, S., Wagner, M., Stahl, D.A., 1997. Population structure of microbial communities asso- ciated with two deep, anaerobic, alkaline aquifers. Applied and Environmental Microbiology, 63: 1498-1504.

Ghosh, S., Setlow, P., 2009. Isolation and characterization of superdormant spores of Bacillus species. Journal of Bacteriology, 191: 1787-1797.

Górecki, W., 2006. Atlas of Geothermal Resources of Mesozoic Formations in the Polish Lowlands. AGH, Kraków.

Griebler, C., Lueders, T., 2009. Microbial biodiversity in groundwater ecosystems. Freshwater Biology, 54: 649-677.

Hicks, R.J., Fredrickson, J.K., 1989. Aerobic metabolic potential of microbial populations indigenous to deep subsurface environments. Geomicrobiology Journal, 7: 67-78.

Ivanova, E.P., Vysotskii, M.V., Svetashev, V.I., Nedashkovskaya O.I., Gorshkova, N.M., Mikhailov, V.V., Yumoto, N., Shigeri, Y., Taguchi, T., Yoshikawa, S., 1999. Characterization of Bacillus strains of marine origin. International Microbiology, 2: 267-271.

Kolago, C., 1964. Wody mineralne województwa szczecińskiego i perspektywy ich wykorzystania (in Polish). Przegląd Zachodniopomorski, 5: 65-85.

Krawiec, A., 1999. New results of the isotope and hydrochemical investigations of therapeutical waters of Ciechocinek Spa (in Polish with English summary). Przegląd Geologiczny, 47: 255-260.

Krawiec, A., Rübel, A., Sadurski, A., Weise, S.M., Zuber, A., 2000. Preliminary hydrochemical, isotope, and noble gas investigations on the origin of salinity in coastal aquifers of western Pomerania, Poland. In: 16th Salt Water Intrusion Meeting: "Hydrogeology of the coastal aquifers": 87-94. UMK, Toruń.

Krumholz, L.R., 2000. Microbial communities in the deep subsurface. Hydrogeology Journal, 8: 4-10.

Liu, K., Jiao, J.J., Gu, J.D., 2014. Investigation on bacterial community and diversity in the multilayer aquifer-aquitard system of the Pearl River Delta, China. Ecotoxicology, 23: 2041-2052.

Liu, S.B., Chen, X.L., He, H.L., Zhang, X.Y., Xie, B.B., Yu, Y., Chen, B., Zhou, B.C., Zhang, Y.Z., 2013. Structure and ecological roles of a novel exopolysaccharide from the Arctic Sea ice bacterium Pseudoalteromonas sp. strain SM20310. Applied and Environmental Microbiology, 79: 224-230.

Lovley, D.R., Goodwin, S., 1988. Hydrogen concentrations as an indicator of the predominant terminal electron-accepting reactions in aquatic sediments. Geochimica et Cosmochimica Acta, 52: 2993-3003

Lovley, D.R., Chapelle, F.H., 1995. Deep subsurface microbial processes. Reviews of Geophysics, 33: 365-381.

Łebkowska, M., Karwowska, E., 2010. Microorganisms present in sulfide waters (in Polish with English summary). Balneologia Polska, 52: 60-63.

Martín, S., Márquez, M.C., Sánchez-Porro, C., Mellado, E., Arahal, D.R., Ventosa, A., 2003. Marinobacter lipolyticus sp. nov., a novel moderate halophile with lipolytic activity. Interna- 
tional Journal of Systematic and Evolutionary Microbiology, 53: 1383-1387.

Missimer, T.M., Hoppe-Jones, C., Jadoon, K.Z., Li, D. Al-Mashharawi, S.K., 2014. Hydrogeology, water quality, and microbial assessment of a coastal alluvial aquifer in western Saudi Arabia: potential use of coastal wadi aquifers for desalination water supplies. Hydrogeology Journal, 22: 1921-1934.

Monteiro, S.M.S., Clemente, J.J., Carrondo, M.J.T., Cunha, A.E., 2014. Enhanced spore production of Bacillus subtilis grown in a chemically defined medium. Advances in Microbiology, 4: 444-454.

Namyslowski, B., 1913. Über unbekannte halophile Mikroorganismen aus dem Innern des Salzbergwerkes Wieliczka. Bulletin International Academy of Science Cracow Series B, 3/4: 88-104.

Onstott, T.C., Phelps, T.J., Kieft, T., Colwell, F.S., Balkwill, D.L., Fredrickson, J.K., Brockman, F.J., 1998. A global perspective on the microbial abundance and activity in the deep subsurface. In: Enigmatic Microorganisms and Life in Extreme Environments (ed. J. Seckbach): 489-499. Kluwer Publisher.

Palomo, S., González, I., de la Cruz, M., Martin, J., Rubén Tormo, J., Anderson, M., Hill, R.T., Vicente, F., Reyes, F., Genilloud, O., 2013. Sponge-derived Kocuria and Micrococcus spp. as sources of the new thiazolyl peptide antibiotic kocurin. Marine Drugs, 11: 1071-1086

Pedersen, K., Ekendahl, S., 1990. Distribution and activity of bacteria in deep granitic groundwaters of Southeastern Sweden. Microbial Ecology, 20: 37-52.
Roohi, A., Ahmed, I., Khalid, N., Iqbal, M., Jamil, M., 2014. Isolation and phylogenetic identification of halotolerant/halophilic bacteria from the salt mines of Karak, Pakistan. International Journal of Agriculture and Biology, 16: 564-570.

Sand, W., 2003. Microbial life in geothermal waters. Geothermics, 32: 655-667.

Sass, A.M., McKew, B.A., Sass, H., Fichtel, J., Timmis, K.N., McGenity, T.J., 2008. Diversity of Bacillus-like organisms isolated from deep-sea hypersaline anoxic sediments. Saline Systems, 4: 8.

Sass, H., Cypionka, H., 2004. Isolation of sulfate-reducing bacteria from the terrestrial deep subsurface and description of Desulfovibrio cavernae sp. nov. Systematic and Applied Microbiology, 27: 541-548.

Walczak, M., Krawiec, A., 2014. Microorganisms in the brines of the Mesozoic strata from the Polish Lowland (in Polish with English summary). Przegląd Geologiczny, 62: 420-423.

Whitman, W.B., Coleman, D.C., Wiebe, W.J., 1998. Prokaryotes: The unseen majority. Proceedings of the National Academy of Sciences USA, 95: 6578-6583.

Zuber, A., Grabczak, J., 1991. On origin of Mesozoic brines in central and Nothern Poland. In: Współczesne problemy hydrogeologii (in Polish with English summary): 202-208. Wydawnictwo SGGW-AR, Warszawa.

Zuber, A., Różański, K., Ciężkowski, W., 2007. Metody znacznikowe $\mathrm{w}$ badaniach hydrogeologicznych (in Polish) 142-148. Wydawnictwo Politechniki Wrocławskiej, Wrocław. 